\title{
The Analysis of the Development Strategy Center of the Increased Use of Domestic Products of the Ministry of Industry
}

\author{
Sondhy Kamesworo ${ }^{1}$, Arief Daryanto ${ }^{2}$, Raden Dikky Indrawan ${ }^{3}$ \\ ${ }^{1,2,3}$ Graduate IPB Business School, Indonesia \\ Corresponding Author: Sondhy Kamesworo
}

DOI: https://doi.org/10.52403/ijrr.20220178

\section{ABSTRACT}

The use of the Analytical Hierarchy Process (AHP) in this study is to help determine the priorities of the strategy from a list of alternative strategies that have been produced by the SWOT matrix. List of alternative development strategy of the organization is obtained through the analysis of external factors and internal factors that affect the performance of the organization. Center of the Increased Use of Domestic Products (P3DN) the Ministry of Industry has strategic objectives to be achieved, however, based on the Annual Performance Report, there are two objectives are not achieved, namely the percentage of the value of the achievements of the use of domestic products in government procurement as well as the value of domestic products used in the process of government procurement. Regarding these conditions the board stated that Pusat P3DN need to formulate the priority strategies that can optimize the capabilities of the organization as well as improve internal weaknesses. The stages of analysis that is implemented to achieve these goals is to do the evaluation of external and internal factors of the organization, to map the position of the organization based on the IE matrix, the set of alternative strategy through SWOT matrix, determine the priority of the strategy with the approach of AHP and finally formulate managerial implications that contains the program of work to support the achievement of the priorities of the strategy selected. The priority of the strategy chosen, among others, the Increase in the implementation of the P3DN through the monitoring and evaluation of
\end{abstract}

government agencies and industry in the country, the Optimization of the campaign and branding P3DN to Government Units as well as Build information systems P3DN as the basis of the work program of the organization.

Keywords: strategy development, SWOT, AHP, Center of the Increased Use of Domestic Products

\section{INTRODUCTION}

In order to develop and improve the competitiveness of domestic industries, the government has issued an industrial empowerment policy based on Government Regulation No. 29 of 2018. Industrial empowerment is an effort by the Central Government and Local Government that is planned, directed, and measured to enable and bathe industry players participatorily in order to improve the competitiveness of national industries. One of the implementations of such policies that support the domestic industry is the obligation to use domestic products.

The Program to Increase the Use of Domestic Products aims to build trust in the strength of one's own nation, able to produce international quality products at competitive prices so as to increase love and pride in domestic products and able to realize the dream to become a resilient, independent, internationally competitive industrial country with a strong industrial structure by 2035 . Optimization of the use of domestic products is expected to ensure 
the independence and stability of the national economy, where the industrial sector will be the driver of the national economy, making Indonesia a producer country not an importer country, has the power to accelerate the spread and equitable development of the overall industry of Indonesia, which is finally able to improve the welfare of the Indonesian people fairly and equitably and strengthen national resilience.

Local product usage requirements have been applied in many developing countries. This policy aims to reduce the inequality between domestic products to imported products in a country, increase national industrial participation in economic activity in certain sectors, create job opportunities so as to increase state income, support economic diversification, encourage synergy between sectors and reduce economic dependence in certain sectors (Nwapi, 2015). According to Owusu and Vaaland (2016) the focus of this policy is to encourage value addition so as to stimulate local capacity growth.

Achieving local improvement of content in every industry sector will encourage the integration of local companies into the industrial structure which will ultimately improve the standard of welfare of the wider community. The value of the domestic content of an item is measured based on the TKDN indicator (Domestic Content Level). Susanti (2016) stated that TKDN (Domestic Component Level) is a limit or value that measures what level of domestic local content in a Product / Service. In measuring TKDN for a product, there are 3 aspects that will be an assessment, namely material, labor, general service costs (overhead).

In recent years more and more stakeholders have voiced the importance of encouraging increased use of domestic products on government projects, ranging from domestic manufacturers to professional practitioners. The President also gave directions related to this issue in the Cabinet Limited Meeting on Evaluation of Domestic Component Level Implementation. The direction of highranking state officials is then contained in Government Regulation No. 29 of 2018 which contains guidelines for the implementation of the Program to Increase the Use of Domestic Products in Government Procurement of Goods / Services.

The implementation of the Domestic Product Use Improvement program faces major challenges today. The condition of the domestic manufacturing industry is experiencing a weakening trend caused by various things. The Covid-19 pandemic that a year hit Indonesia is certainly very influential on this condition, one of the indicators that can be seen is a decrease in the utilization rate of domestic industries. This condition certainly greatly affects the performance of the P3DN Center in achieving the organization's strategic goals that have been set. Previously, the Ministry of Industry in the Strategic Plan 2020 - 2024 has set strategic targets related to indicators of the use of domestic products, namely:

Table 1 Strategic Goals of the Ministry of Industry Related to P3DN

\begin{tabular}{|l|l|l|l|l|l|l|}
\hline Goal & Unit & $\mathbf{2 0 2 0}$ & $\mathbf{2 0 2 1}$ & $\mathbf{2 0 2 2}$ & $\mathbf{2 0 2 3}$ & $\mathbf{2 0 2 4}$ \\
\hline $\begin{array}{l}\text { Percentage of the percentage of the value of the use of domestic products in } \\
\text { the procurement of government goods and services }\end{array}$ & Percentage & 46,63 & 48,02 & 49,47 & 50,95 & 52,48 \\
\hline The value of domestic products used in the government procurement process & $\begin{array}{l}\text { Trillions of } \\
\text { Rupiah }\end{array}$ & 1,0 & 1,25 & 1,5 & 1,7 & 2,0 \\
\hline The number of TKDN certified products $\geq 25 \%$ that are still valid & Product & 6.200 & 6.630 & 7.130 & 7.640 & 8.400 \\
\hline
\end{tabular}

In order to achieve the strategic objectives in question, the P3DN Center has implemented several work programs such as the issuance of TKDN Certification, supervision and resolution of disputes related to the use of domestic products and harmonization of regulations related to P3DN between Ministries / Institutions. The 
implementation of this work program in fact has not given positive results to the achievement of organizational performance because based on the P3DN Government Agency Performance Accountability Report 2020 There are 2 (two) strategic targets that are not achieved the target, namely the percentage of the value of the use of domestic products in the procurement of government goods and services and domestic products used in the government procurement process. The full data is as follows:

Table 2 Achievements of P3DN Central Organization Performance in 2020

\begin{tabular}{|c|c|c|c|}
\hline Goal & Unit & Target & Realization \\
\hline $\begin{array}{l}\text { Percentage of the percentage of the value of the use of domestic products in the procurement } \\
\text { of government goods and services }\end{array}$ & Percentage & 46,63 & 30 \\
\hline The value of domestic products used in the government procurement process & $\begin{array}{l}\text { Trillions } \\
\text { Rupiah }\end{array}$ & 1,0 & 0 \\
\hline The number of TKDN certified products $\geq 25 \%$ that are still valid & Product & 6.200 & 9.845 \\
\hline
\end{tabular}

The achievement of P3DN Center performance is influenced by various external and internal conditions of the organization. Initial identification of external conditions that are considered to affect the organization, among others, is still lack of coordination and close cooperation between the P3DN Center and other government agencies, there are still many agencies. government that has not complied with the provisions of regulations related to P3DN and not optimal supervision of P3DN on government projects. On the other hand, internal organizational weaknesses that contribute greatly to the achievement of organizational performance include a limited amount of human resources, a limited amount of budget. as well as the absence of p3DN information systems that accommodate data and information related to the procurement performance of goods/services between government agencies.

Seeing this, the P3DN Center is very necessary to formulate a new priority strategy taking into account the external and internal conditions of the organization so that the achievement of organizational performance is in accordance with the target targets. Strategic set. Based on the background of the defense in this study, it can be formulated the problems that will be discussed are:

1. How are the external and internal conditions of the Ministry of Industry's
P3DN Center affecting the achievement of organizational performance targets?

2. What are the alternative strategies that can be implemented by the P3DN Center to achieve organizational performance targets?

3. What is the right priority strategy for the P3DN Center organization?

\section{METHODS}

Research design uses quantitative and qualitative approaches. Quantitative approach by conducting an online survey of employees of PT. XYZ, then for qualitative approach conducted in-depth interview method with the management. Data collection was conducted in October 2021, with samples spread across Jakarta, Surabaya and Medan.

In this study the method used is a quantitative and descriptive approach through case studies to identify the problem faced in the research object. Descriptive analysis is generally used to provide an overview of information, explanations and conditions of the research object so that it is known the influence of strategic factors on the development efforts of the P3DN Central organization. The data that will be used in this study is primary data and secondary data. Primary data is data obtained directly through the interview process or in depth interview with respondents that have been determined, while secondary data is data obtained from literature studies as well as literature from 
various relevant sources. The research was conducted at the Central Working Unit on The Use of Domestic Products, Ministry of Industry located at Jalan Gatot Subroto Kavling 52 South Jakarta in the period August 2021 - October 2021.

The method of determining samples is used through purposive sampling techniques. In determining the respondents who will be interviewed to get primary data will use the expertise judgement approach. Benini (2017) said expert judgement is an assessment of the analysis or opinion of data and information on a problem object carried out by someone who has an advantage in terms of understanding, ability and experience related to the problem.

This research analysis phase starts from evaluating external strategic factors with the help of pestel approach (Political, Economic, Social, Technology, Ecology and Legality) and porter's five competing forces. PesteL approach has two basic functions to the organization, namely identifying the organization's operational environment and providing data and information in order to predict situations and conditions that may occur in the future and develop anticipation strategies (Yuksel, 2012). The next stage is the evaluation of internal strategic factors and continued the strategy matching stage by creating an external internal matrix (IE). It is necessary to map the position of the organization so that it can be recommended a strategy that matches its quadrant.

SWOT analysis will then produce alternative strategies that are classified into so (Strength-Opportunities) strategy categories, ST strategies (Strength-Threads), WO (Weakness-Opportunities) strategies and WT (Weakness-Threads) strategies. The final stage of analysis is to determine strategy priorities by utilizing the AHP (Analytical Hierarchy Process) approach, analysis can be used for decision-making complex problems such as planning, alternative strategy preparation, strategy prioritization, selection. wisdom, resource allocation, need projection, preparation of action plans, optimization, and conflict resolution are more objective and subjective (Sulistiyani, 2017).

\section{RESULTS}

The Center for The Improvement of Domestic Product Use (P3DN) is a Working Unit established in 2019 on the basis of the regulation of the Minister of Industry No. 35 / M-IND / PER / 11/2018 on the Organization and Working Procedures of the Ministry of Industry. The P3DN Center has the task of carrying out the preparation of technical policies, plans, programs, implementation, monitoring, evaluation and reporting in the field of increasing the use of domestic products. Visi PusatP3DN is fully supported the contents of the President of the Republic of Indonesia, namely "The Realization of a Sovereign, Independent and Personal Advanced Indonesia based on Gotong-Royong". While the vision of Industrial Development is "Realizing Indonesia to become a Competitive Industrial Country with a Strong Industrial Structure Based on Natural Resources.

The purpose of the establishment of the Central Working Unit of P3DN is to increase the use of domestic products by the Government, Business Entities and Communities, empower domestic industries through the security of the domestic market, reduce dependence on imported products and increase domestic added value and locally. strengthen the structure of the industry by increasing the use of capital goods, raw materials, components, technology and human resources from within the country.

External strategic factors are evaluated, there are ten (10) strategic factors that affect the sustainability of the organization. This is obtained from the results of interviews and discussions with the leadership of the P3DN Center. Evaluation external factors mean assessing achievement / performance that is a factor of opportunities and threats that exist to achieve organizational goals. This analysis is focused on existing conditions and trends 
Sondhy Kamesworo et.al. The analysis of the development strategy center of the increased use of domestic products of the ministry of industry.

that arise from the outside, but can influence organizational performance (Masa, 2014).

The main opportunity factor chosen by expert respondents as seen in table 3 is the socialization and supervision of the use of domestic products in other Work Units supported by the P3DN National Team and the Ministry's P3DN Team. Expert respondents gave a weighting score of 0.110 with a rating of 4 so that the score was 0.440 . The main threat factor chosen by expert respondents is the number of Government Work Units that have not prioritized domestic products on their procurement plans. Expert respondents gave a weighting score of 0.112 with a rating of 3 so that the score was 0.337 .

Table 3 Results of External Strategic Factor Evaluation

\begin{tabular}{|c|c|c|c|c|}
\hline No. & External Strategic Factors & Weight & Rating & Score \\
\hline & Chance & & & \\
\hline 1 & Socialization and promotion of P3DN programs assisted by the P3DN National Team & 0,110 & 4 & 0,440 \\
\hline 2 & Large amount of goods and capital expenditure budget in the state budget & 0,105 & 2 & 0,211 \\
\hline 3 & There is a proud trend of using local products in indonesian society & 0,098 & 3 & 0,294 \\
\hline 4 & The President supports the P3DN program as stated in the RPJMN & 0,110 & 4 & 0,440 \\
\hline \multirow[t]{2}{*}{5} & No other Unit of Work has the authority such as the P3DN Center. & 0,089 & 3 & 0,266 \\
\hline & Threat & & & \\
\hline 1 & $\begin{array}{l}\text { There is no source of valid reference data related to the plan report and the realization of the use of } \\
\text { domestic products between Work Units. }\end{array}$ & 0,100 & 3 & 0,300 \\
\hline 2 & The development of imported product technology is considered better than local products. & 0,096 & 2 & 0,191 \\
\hline 3 & There are still many Work Units that have not complied with P3DN regulations. & 0,112 & 3 & 0,337 \\
\hline 4 & International parties consider P3DN regulations to violate free trade. & 0,079 & 3 & 0,237 \\
\hline \multirow[t]{2}{*}{5} & Economic growth and public consumption are declining due to pandemics. & 0,100 & 3 & 0,300 \\
\hline & Total & 1,00 & & 2,931 \\
\hline
\end{tabular}

The evaluation of the internal strategic factors of the P3DN Central organization as seen in table 4 results in ten strategic factors that include strengths and weaknesses. The main strength factor chosen by expert respondents is the obligation to use domestic products supported by many laws and regulations from the central government which has the highest score of 0.447 , while the main disadvantage factor chosen by expert respondents is not yet have an information system that supports the functions of socialization, supervision and evaluation. Respondents gave a weight of 0.103 and a rating of 1 so that the score was 0.103 .

Table 4 Results of Internal Strategic Factor Evaluation

\begin{tabular}{|c|c|c|c|c|}
\hline No. & Internal Strategic Factors & Weight & Rating & Score \\
\hline & Strength & & & \\
\hline 1 & Obligation to use domestic products based on applicable laws and regulations & 0,112 & 4 & 0,447 \\
\hline 2 & Have the authority to sign and revoke the TKDN Certificate & 0,110 & 4 & 0,438 \\
\hline 3 & Ministry of Industry serves as the daily head of the P3DN National Team & 0,098 & 3 & 0,295 \\
\hline 4 & The P3DN Center is authorized to publish an Inventory List of Domestic Production Goods & 0,098 & 4 & 0,393 \\
\hline \multirow[t]{2}{*}{5} & P3DN center authorized to conduct audit of TKDN value consistency & 0,100 & 4 & 0,402 \\
\hline & Debilitation & & & \\
\hline 1 & The number of HUMAN RESOURCES has not supported the implementation of the work program & 0,094 & 2 & 0,187 \\
\hline 2 & Limited budget & 0,091 & 2 & 0,183 \\
\hline 3 & We don't have an information system that supports organizational performance. & 0,103 & 1 & 0,103 \\
\hline 4 & $\begin{array}{l}\text { The P3DN Center does not yet have an SOP for monitoring, controlling and evaluating the } \\
\text { achievements of TKDN. }\end{array}$ & 0,096 & 2 & 0,192 \\
\hline \multirow[t]{2}{*}{5} & The P3DN Center does not yet have close coordination and cooperation with many Work Units. & 0,098 & 2 & 0,196 \\
\hline & Total & 1,00 & & 2,836 \\
\hline
\end{tabular}

The next stage will be an analysis of the position of the P3DN Central organization using the External Internal matrix. External Internal Analysis is useful for knowing the position of the P3DN Center so that it can be recommended a general strategy that is suitable to be applied by the P3DN Center based on the weight score of its strategic factors. In figure 1 , the results of external internal analysis of the P3DN Center organization show that the organization mapping is in quadrant $\mathrm{V}$ which belongs to the guard and maintain 
Sondhy Kamesworo et.al. The analysis of the development strategy center of the increased use of domestic products of the ministry of industry.

category with a total IFE score of 2,836 and the total value of EFE score is 2,913.

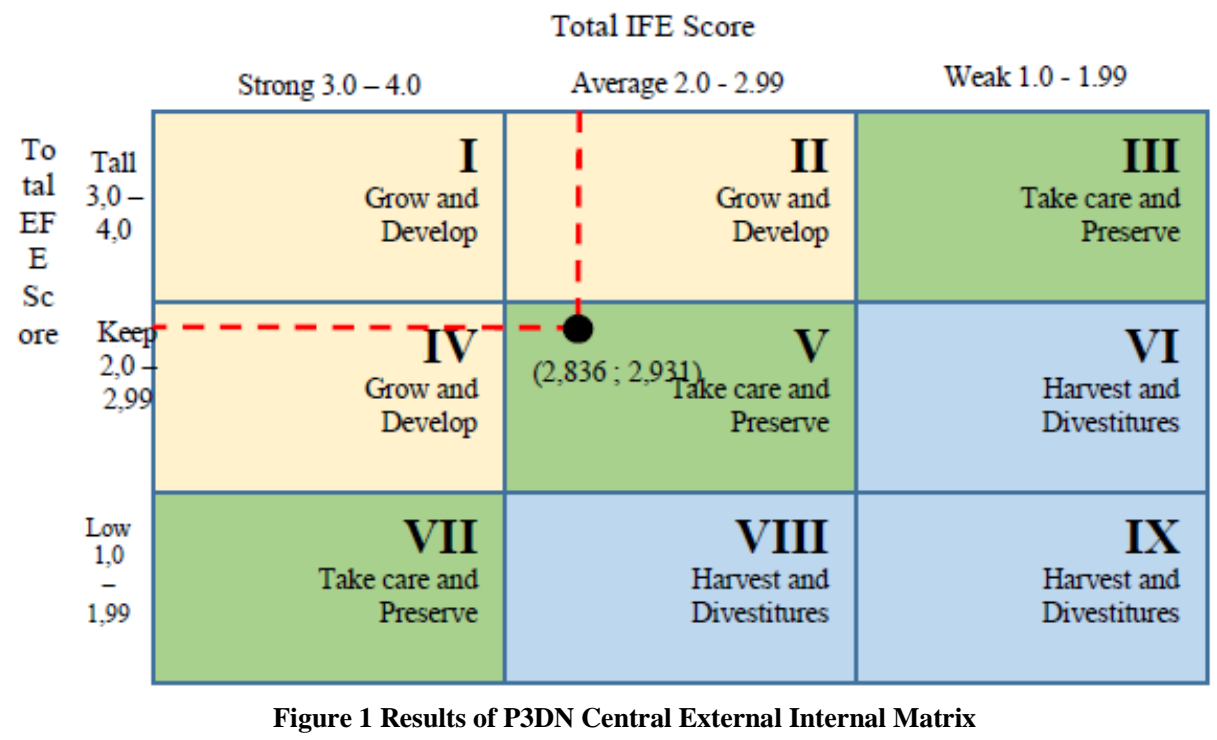

For organizations that are in the guard and maintain category, David (2017) suggests that organizations that are in this category can choose market penetration and product development strategies. In line with the mapping of organizations that are in the category of guard and maintain which means that the organization's performance is in the average position. Seeing the many organizational performance targets that must be achieved, the P3DN center is recommended to improve the organization's internal weaknesses and optimize authority in encouraging the implementation of the use of domestic products, so that the organization can achieve its strategic goals and answer the demands and needs of external stakeholders.

In accordance with the recommendations of the IE matrix, the P3DN Center is advised to focus on increasing the effectiveness of strategies that are already running and optimizing organizational authority. Strategies that are considered necessary to be optimized include monitoring the use of domestic products on government projects, monitoring and evaluation of government agencies and domestic industries and P3DN program campaigns. The next recommendation is to make a breakthrough new strategy, this is considered necessary because the performance of the organization's achievement is not developed due to the nonresponseoftheP3DN Central organization to the performance of procurement of government goods and services and problems related to violations of domestic product use provisions. The new strategy that can be implemented by the P3DN Center is the creation of P3DN information systems and the integration of government procurement data.

Swot matrix analysis in table 5 shows seven alternative strategies that are in accordance with organizational conditions, namely (1) Optimization of monitoring of TKDN commitments in large-value government projects (2) Optimization of P3DN campaigns and branding to Government Work Units (3) Building Integration of goods /services procurement data between Ministries (4) Supervision and enforcement of compliance with P3DN regulations (5) Building $\mathrm{P} 3 \mathrm{DN}$ information system as the basis of the organization's work program (6) Increase intensive cooperation between the Ministry of Industry and the P3DN Team of other Ministries (7) Build superior internal human resources. 
Sondhy Kamesworo et.al. The analysis of the development strategy center of the increased use of domestic products of the ministry of industry.

Table 5 SWOT Matrix of P3DN Center of the Ministry of Industry

\begin{tabular}{|c|c|c|}
\hline & POWER (S) & WEAKNESS (W) \\
\hline & $\begin{array}{l}\text { Domestic product use obligations are } \\
\text { based on applicable laws and } \\
\text { regulations }(0.440)\end{array}$ & $\begin{array}{l}\text { The number of human resources has } \\
\text { not supported the implementation of } \\
\text { the work program }(0,187)\end{array}$ \\
\hline & $\begin{array}{l}\text { Have the authority to sign and revoke } \\
\text { the TKDN Certificate }(0.438)\end{array}$ & Limited budget $(0.183)$ \\
\hline & $\begin{array}{l}\text { Ministry of Industry serves as daily } \\
\text { chairman of the P3DN National Team } \\
(0.295)\end{array}$ & $\begin{array}{l}\text { Does not yet have an information } \\
\text { system that supports organizational } \\
\text { performance }(0.103)\end{array}$ \\
\hline & $\begin{array}{l}\text { P3DN Center authorized to publish } \\
\text { Inventory List of Domestic Production } \\
\text { Goods (0.393) }\end{array}$ & $\begin{array}{l}\text { The P3DN Center does not yet have } \\
\text { an SOP in terms of supervision, } \\
\text { control and evaluation of TKDN } \\
\text { achievements }(0,192)\end{array}$ \\
\hline & $\begin{array}{l}\text { P3DN center authorized to conduct an } \\
\text { audit of the consistency of TKDN } \\
\text { values }(0.402)\end{array}$ & $\begin{array}{l}\text { The P3DN Center does not yet have } \\
\text { close coordination and cooperation } \\
\text { with many Work Units }(0.196)\end{array}$ \\
\hline OPPORTUNITY $(\mathrm{O})$ & S-O STRATEGY & W-O STRATEGY \\
\hline $\begin{array}{l}\text { 1. Socialization and promotion of P3DN programs } \\
\text { assisted by the P3DN National Team }(0,440)\end{array}$ & \multirow{2}{*}{$\begin{array}{l}\text { Optimization of TKDN commitment } \\
\text { monitoring in large-value government } \\
\text { projects ( } \mathrm{S} 1, \mathrm{~S} 3, \mathrm{O} 2, \mathrm{O} 4)\end{array}$} & \multirow{2}{*}{$\begin{array}{l}\text { Building a P3DN information system } \\
\text { as the basis of an organization's work } \\
\text { program }(\mathrm{W} 3, \mathrm{O} 4, \mathrm{O} 5)\end{array}$} \\
\hline $\begin{array}{l}\text { 2. Large amount of goods and capital expenditure } \\
\text { budget in the State Budget }(0.316)\end{array}$ & & \\
\hline $\begin{array}{l}\text { 3. There is a proud trend of using local products in } \\
\text { indonesian society }(0,294)\end{array}$ & \multirow{3}{*}{$\begin{array}{l}\text { Optimization of P3DN campaigns and } \\
\text { branding to Government Task Force } \\
\text { (S1,S3,O1,O3) }\end{array}$} & \multirow{3}{*}{$\begin{array}{l}\text { Increaseintensive communication } \\
\text { between the Ministry of Industry and } \\
\text { other Ministry P3DN Teams (W5, } \\
\text { O1, O5) }\end{array}$} \\
\hline $\begin{array}{l}\text { 4. The President supports the P3DN program as } \\
\text { stated in the RPJMN }(0,440)\end{array}$ & & \\
\hline $\begin{array}{l}\text { 5. No other Unit of Work has authority such as } \\
\text { P3DN Center }(0.260)\end{array}$ & & \\
\hline THREAT (T) & S-T STRATEGY & W-T STRATEGY \\
\hline $\begin{array}{l}\text { 1. There is no source of valid reference data related } \\
\text { to the plan report and realization of the use of } \\
\text { domestic products between Work Units }(0.300)\end{array}$ & $\begin{array}{l}\text { Building integration of goods/services } \\
\text { procurement data between Ministries } \\
\text { (S1,S4,T1) }\end{array}$ & $\begin{array}{l}\text { Building superior internal human } \\
\text { resources }(\mathrm{W} 1, \mathrm{~W} 4, \mathrm{~T} 3)\end{array}$ \\
\hline $\begin{array}{l}\text { 2. The development of imported product technology } \\
\text { is considered better than local products. }\end{array}$ & \multirow{3}{*}{$\begin{array}{l}\text { Supervision and enforcement of } \\
\text { compliance with P3DN regulations } \\
(\mathrm{S} 1, \mathrm{~S} 5, \mathrm{~T} 3, \mathrm{~T} 5)\end{array}$} & \\
\hline $\begin{array}{l}\text { 3. There are still many Work Units that have not } \\
\text { complied with P3DN regulations }(0.337)\end{array}$ & & \\
\hline $\begin{array}{l}\text { 4. International parties consider P3DN regulations to } \\
\text { violate free trade }(0.237)\end{array}$ & & \\
\hline $\begin{array}{l}\text { 5. Economic growth and public consumption } \\
\text { declined due to pandemic }(0,300)\end{array}$ & & \\
\hline
\end{tabular}

SO strategy. Optimization of authority is the main focus of this strategy, expert respondents choose organizational authority which is the main force is monitoring the use of domestic products in government projects as well as socializing and campaigning domestic product use policies. To optimize this authority, the P3DN Center needs to increase intensive coordination and cooperation with the Ministry of Maritime Affairs, Ministry of Economic Affairs, Ministry of SOEs, Linstitute of Government Procurement and Services (LKPP) policy and The Agency for the Assessment and Application of Technology (BPPT). This strategy is very important to run because if large-value projects optimized for domestic products will have a positive effect on the growth of domestic industries, in addition, this can be an example of enforcing P3DN rules.
STstrategy. This strategy is based on how the organization uses its internal strengths to anticipate potential threats that could hinder the organization's growth and its efforts in achieving performance targets. Through monitoring and evaluation of government agencies and domestic industries, it is expected that the P3DN Center can increase compliance of other government agencies on the obligation to use domestic products in the procurement of government goods / services so that more local products are absorbed and will have a positive effect on the growth of domestic industries. An alternative to the new strategy that appears in this category is the integration of goods / services procurement data between ministries. The realization of this constellation in teg will facilitate mapping of the needs of goods by government agencies so that the P3DN Center can provide recommendations for 
Sondhy Kamesworo et.al. The analysis of the development strategy center of the increased use of domestic products of the ministry of industry.

domestic goods thanks to mandatory categories.

WOstrategy. The P3DN center has several weaknesses that can hinder the development of the organization, including lack of coordination and cooperation with other government agencies. This weakness needs to be overcome because the implementation of P3DN as a whole requires a lot of coordination and good cooperation between the P3DN Center and other Work Units. This discovers many aspects of harmonization of regulations between agencies, socialization and promotion of domestic products as import substitution. In this category, a new strategy is also proposed, namely the creation of a P3DN Information System that will accommodate a database of performance reporting on the use of domestic products between government agencies, domestic product data that has tkdn certificates and complaints of violations of P3DN provisions on procurement of goods / services. Through this information system, it is expected that the head of the P3DN Center can determine executive judgement based on valid real time data.

WTstrategy. The impact of external threats on the achievement of P3DN Central organization performance is quite large, therefore internal weaknesses that must be addressed immediately according to expert respondents are the improvement of internal human resources. This revamp aims so that the P3DN Center can carry out its basic tasks and functions properly. The scope includes recalculating the workload of
P3DN Centeremployees of employee competence with current positions and training level to fill the competence of employees in accordance with regulation.

Previously SWOT analysis has produced a list of alternative strategies that are suitable to be implemented by the P3DN Center in order to achieve its performance targets. The next final stage analysis is to use the Analytic Hierarchy Process (AHP) method to determine the priorities of the organization's development strategy. To analyze AHP, it is necessary to arrange a hierarchy first, Ayuningtyas (2019) added that the identification of hierarchy forming components is precisely very influential in producing AHP analysis that is in accordance with organizational objectives. Based on discussions with expert respondents and reviewing previous research, the hierarchy in this study was set at 4 levels. The first level is the objective of the strategy formulation, the second level is the four groups of factors defined in the SWOT matrix, the third level is the strategic factor that belongs to the SWOT factor and the fourth level is the strategy that must be evaluated.

Weighting by expert respondents is the next step in AHP analysis, the numbers obtained are then processed using the Expert Choice 11program. This program will synthesize the influence of actors, factors and criteria on alternative strategies to be tested so that strategic priorities are obtained for the P3DN center. The results of weight processing and priority strategies can be seen as follows:

Table 6 Weights and Priorities Influence of Alternative Strategies on Goals
\begin{tabular}{|l|l|l|}
\hline Alternative Strategies & Weight & Priority \\
\hline Optimization of monitoring of TKDN commitments in large-value government projects & 0,148 & 4 \\
\hline Optimization of P3DN campaigns and branding to government task force & 0,182 & 2 \\
\hline Building integration of goods/services procurement data between Ministries & 0,117 & 6 \\
\hline Supervision and enforcement of compliance with P3DN regulations & 0,185 & 1 \\
\hline Build a P3DN information system as the basis of an organization's work program & 0,166 & 3 \\
\hline Increasing intensive communicationbetween the Ministry of Industry and other Ministry P3DN Teams & 0,134 & 5 \\
\hline Build superior internal human resources & 0,069 & 7 \\
\hline
\end{tabular}

In table 6 , it can be seen based on the results of weighting of all alternative swot analysis strategies obtained alternative strategies that are the main priority for the
P3DN Center is the regulation and enforcement of compliance withP3DN regulations with a weight assessment of 0.185 from expert respondents. The second 
Sondhy Kamesworo et.al. The analysis of the development strategy center of the increased use of domestic products of the ministry of industry.

strategic priority is optimization of P3DN campaigns and branding to the Government Task Force with a weighting value of 0.182 from expert respondents, then the third strategic priority is to develop theP3DN information system as the basis of the organization's work program with a weight assessment of 0.166 from expert respondents.

The results of vertical analysis on each priority in the AHP hierarchy can be explained as follows, a selected priority strategy to achieve the target of development of the P3DN Center organization is the improvement of $\mathrm{P} 3 \mathrm{DN}$ implementation through monitoring and evaluation of government agencies and domestic industries, this strategy was chosen because it is in line with the main strategic factors owned by the P3DN Center, namely the obligation to use products. Domestically based on applicable laws and regulations so that all Work Units are obliged to implement P3DN implementation because there are binding regulations. Utilizing organizational strength factors as the direction of organizational development is in line with the assessment of expert respondents who assess that strength factors have the highest level of importance compared to weakness, opportunity and threat factors.

Strategy priorities that have been determined through AHP analysis are then translated into work programs that support the achievement of performance targets. From the organization's point of view, the prioritization of this strategy is intended so that the P3DN Center can allocate resources that are efficiently owned to activities or work plans that have the highest level of interest with the results of the achievement of these activities have a significant impact on the overall performance of the organization. The strategic target that must be achieved by the P3DN Center is the percentage of the achievement value of the use of domestic products in the procurement of government goods and services by $49.47 \%$ in 2022 and domestic products used in the government procurement process of Rp 1.5 trillion for 2022. To support the achievement of the recommended work program can be seen in table 7 .

Table 7 Managerial Implications of P3DN Center Development of the Ministry of Industry

\begin{tabular}{|c|c|c|c|c|c|}
\hline No. & Priority Strategy & & Work Program & & Output \\
\hline \multirow[t]{3}{*}{1} & \multirow{3}{*}{$\begin{array}{l}\text { Supervision and } \\
\text { enforcement of } \\
\text { compliance with } \\
\text { P3DN regulations }\end{array}$} & 1 & $\begin{array}{l}\text { Building a database application of goods / } \\
\text { services procurement plan and realization of the } \\
\text { use of domestic products; }\end{array}$ & 1 & $\begin{array}{l}\text { Application to accommodate databases of } \\
\begin{array}{l}\text { procurement } \\
\text { agencies }\end{array}\end{array}$ \\
\hline & & 2 & $\begin{array}{l}\text { Conducting supervision on the procurement of } \\
\text { goods / services of great value in government } \\
\text { agencies; }\end{array}$ & 2 & $\begin{array}{l}\text { Recommendations on the results of compliance } \\
\text { supervision of domestic product use at the } \\
\text { central level }\end{array}$ \\
\hline & & 3 & $\begin{array}{l}\text { Drafting a scheme of fines and sanctions against } \\
\text { the person in charge of procurement of goods / } \\
\text { services }\end{array}$ & 3 & $\begin{array}{l}\text { Technical instructions for the imposition of } \\
\text { sanctions and fines }\end{array}$ \\
\hline \multirow[t]{5}{*}{2} & \multirow{5}{*}{$\begin{array}{l}\text { Optimization of } \\
\text { P3DN campaigns } \\
\text { and branding to } \\
\text { government task } \\
\text { force }\end{array}$} & 1 & Establishment of a P3DN Campaign Team; & 1 & The formation of the P3DN Campaign Team \\
\hline & & 2 & $\begin{array}{l}\text { Preparation of an action plan for the P3DN } \\
\text { program's communication strategy and media } \\
\text { campaign; }\end{array}$ & 2 & $\begin{array}{l}\text { Action plan communication strategy and } \\
\text { campaign themeTimetable }\end{array}$ \\
\hline & & 3 & $\begin{array}{l}\text { Establishment of communication forums with } \\
\text { mass media journalists; }\end{array}$ & 3 & $\begin{array}{l}\text { Forum communication press release news } \\
\text { related to P3DN }\end{array}$ \\
\hline & & 4 & $\begin{array}{l}\text { Exhibition and promotion of superior domestic } \\
\text { products; }\end{array}$ & 4 & Domestic product promotion event \\
\hline & & 5 & $\begin{array}{l}\text { P3DN award to government agencies and } \\
\text { domestic producers; }\end{array}$ & 5 & $\begin{array}{l}\text { Award events for domestic producers and } \\
\text { Government Work Units }\end{array}$ \\
\hline \multirow[t]{5}{*}{3} & \multirow{5}{*}{$\begin{array}{l}\text { Build an } \\
\text { information } \\
\text { system that } \\
\text { accommodates } \\
\text { information on the } \\
\text { realization of the } \\
\text { use of domestic } \\
\text { products }\end{array}$} & 1 & $\begin{array}{l}\text { Development of P3DN performance reporting } \\
\text { application of Government Work Unit; }\end{array}$ & 1 & $\begin{array}{l}\text { Application of procurement planning reporting } \\
\text { b/j and realization of domestic product purchases }\end{array}$ \\
\hline & & 2 & $\begin{array}{l}\text { Development of TKDN complaint application } \\
\text { for domestic manufacturers; }\end{array}$ & 2 & $\begin{array}{l}\text { Application of complaint of violation of P3DN } \\
\text { regulations by the Government Work Unit }\end{array}$ \\
\hline & & 3 & P3DN website development; & 3 & $\begin{array}{l}\text { P3DN website that contains regulations and } \\
\text { recapitulation of TKDN certificates }\end{array}$ \\
\hline & & 4 & Network and server infrastructure development & 4 & $\begin{array}{l}\text { P3DN information system support servers and } \\
\text { networks }\end{array}$ \\
\hline & & 5 & $\begin{array}{l}\text { Socialization and technical guidance on the use } \\
\text { of P3DN Information Systems to the general } \\
\text { public }\end{array}$ & 5 & $\begin{array}{l}\text { Increased use of P3DN information systems by } \\
\text { Government Work Units and domestic } \\
\text { manufacturers }\end{array}$ \\
\hline
\end{tabular}


Sondhy Kamesworo et.al. The analysis of the development strategy center of the increased use of domestic products of the ministry of industry.

\section{CONCLUSION}

The results of alternative strategy analysis through AHP with the results of analysis mapping the position of the organization through an external internal matrix then both showed corresponding results. In the external internal matrix mentioned the position of the P3DN Central organization is in the category of guard and maintain, then the combination of three alternative priority strategies selected through AHP analysis is an overview of strategic steps to maintain organizational stability which includes optimizing organizational authority and capabilities and creating new strategies to improve organizational performance. Alternative strategies for monitoring and enforcement of compliance with P3DN regulations and optimization of P3DN campaigns and branding to the Government Task Force are the picture of the P3DN Center in increasing organizational authority in terms of coordinating and directing work programs between government agencies related to P3DN.

\section{Acknowledgement: None}

Conflict of Interest: None

\section{Source of Funding: None}

\section{REFERENCES}

1. Ayuningtyas M. 2019. Strategy Development on Geothermal Value Chain Activities (Study at PT Geo DipaEnergi (Persero)). Journal of Business Strategy. Vol 28(1): 56-78.

2. Benini AP, Chataigner, Noumri N, Parham N, Sweeney J and Tax L. 2017. The Use of
Expert Judgment in Humanitarian Analysis - Theory, Methods, Applications. Geneva (Switzerland). Assessment Capacities Project - ACAPS.

3. David FR and David FR. 2017. Strategic Management concepts andcases A Competitive Advantage Approach. 16th Ed. Essex (England). Pearson Education Limited.

4. Ministry of Industry. 2020. Improving Domestic Industrial Resilience In Pandemic Times. http://kemenperin.go.id. [March 24, 2021].

5. Ma time. 2014. Telemedicine Implementation Development Strategy in South Sulawesi. Journal of Telecommunications and Computers. Vol 5(3): 227 - 250.

6. Nwapi, Chilenye. 2015. Defining the "Local" in Local Content Requirements in the Oil and Gas and Mining Sectors in Developing Countries. Law and Development Review. Vol 8(1): 187-216.

7. Owusu RA and Vaaland TI. 2016. A Business Network Perspective On Local Content In Emerging African Petroleum Nations. International Journal of Energy Sector Management. Vol 10(4): 594-616.

8. Susanti I. 2016. Evaluation of The Quality of Domestic Component Level Certification Services (TKDN) at PT Sucofindo (Persero). Journal for sure. Vol X(1): 87-97.

9. Yuksel I. 2012. Developing a Multi-Criteria Decision Making Model for PESTEL Analysis. International Journal of Business and Management. Vol 7(24): $52-66$.

How to cite this article: Sondhy Kamesworo, Arief Daryanto, Raden Dikky Indrawan. The analysis of the development strategy center of the increased use of domestic products of the ministry of industry. International Journal of Research and Review. 2022; 9(1): 666-675. DOI: https://doi.org/10.52403/ijrr.20220178 